\title{
Estimation of daily global solar irradiance from the air temperature in the state of Paraná, Brazil
}

\author{
Carolina K. Sgarbossa ${ }^{1}$ \& Jorim S. das Virgens Filho ${ }^{2}$ \\ ${ }^{1}$ Universidade Estadual de Ponta Grossa/Mestrado em Engenharia Sanitária e Ambiental. Ponta Grossa, PR, Brasil. E-mail: carolina.sgarb@gmail.com \\ (Corresponding author) - ORCID: 0000-0001-6358-0995 \\ ${ }^{2}$ Universidade Estadual de Ponta Grossa/Laboratório de Estatística Aplicada e Computacional. Ponta Grossa, PR, Brasil. E-mail: jvirgens@uepg.br - \\ ORCID: 0000-0003-2722-9481
}

\begin{abstract}
Global solar irradiance (GSI) is a fundamental source of energy on Earth. Despite its importance, sunshine or solar irradiance data are rarely available from weather stations. In the absence of available data, there are empirical methods that can be used to estimate solar irradiance. The objective of this study is to calibrate the parameters and to evaluate the performance of four empirical models of solar irradiance estimation (those of Chen, Hargreaves, Hunt, and Richardson) from air temperature data for eight localities in the state of Paraná, Brazil. Data were obtained from the Meteorological Database for Teaching and Research (BDMEP). For the comparison of means among the models, the Kruskal-Wallis non-parametric test was used. Dunn's multiple comparison tests were used to analyze which models presented different means from the others. The performance of each model was assessed using the indices Pearson correlation coefficient ( $r$ ), mean bias error (MBE), root mean square error (RMSE), Wilmott concordance index (d), performance index (c) and the Nash-Sutcliffe efficiency (NSE) coefficient. It was observed that the models proposed by Chen and Hunt presented the best performances in the estimation of GSI for the studied Paraná state localities, given that they yielded results which are closer to the observed historical data.
\end{abstract}

Key words: empirical models, model calibration, sunshine hours

\section{Estimativa da irradiância solar global diária a partir da temperatura do ar no Estado do Paraná, Brasil}

RESUMO: A irradiância solar global é a fonte fundamental de energia na Terra. Apesar da sua importância, os dados de insolação ou irradiância solar raramente estão disponíveis em estações meteorológicas. Na ausência de dados disponíveis, há métodos empíricos que podem ser utilizados para estimar a irradiância solar. O estudo objetivou estimar os parâmetros e avaliar os desempenhos de quatro modelos empíricos de estimativa de irradiância solar diária (Chen, Hargreaves, Hunt e Richardson) a partir de dados de temperatura do ar para oito localidades do Estado do Paraná. Foram obtidos dados do Banco de Dados Meteorológicos para Ensino e Pesquisa (BDMEP). Para comparação de médias entre os modelos, foi utilizado o teste não-paramétrico de Kruskal-Wallis, e o teste de comparação múltipla de Dunn para analisar quais modelos apresentaram médias distintas entre si. O desempenho de cada modelo foi avaliado por meio dos índices: coeficiente de correlação de Pearson (r), erro médio de viés (MBE), raiz quadrada do quadrado médio do erro (RMSE), índice de concordância de Wilmott (d), índice de desempenho (c) e coeficiente de eficiência de Nash-Sutcliffe (NSE). Constatou-se que os modelos propostos por Chen e por Hunt apresentaram os melhores desempenhos na estimativa da irradiância solar global para as localidades paranaenses estudadas, por se aproximarem mais dos dados históricos observados.

Palavras-chave: modelos empíricos, calibração de modelos, horas de brilho solar

Editor responsible: Walter Esfrain Pereira

Ref. 222986 - Received 22 Apr, 2019• Accepted 03 Jun, 2020 • Published 30 Jun, 2020 


\section{INTRODUCTION}

Solar irradiance is the main source of energy driving chemical, physical, and biological processes. Moreover, global solar irradiance (GSI) pertains to the amount of solar energy that reaches the Earth's surface. Despite its importance, sunshine, or solar irradiance data is rarely available from meteorological weather stations. Furthermore, the existing data series are relatively scarce for climate studies and they often exhibit discontinuities or failures (Podestá et al., 2004; Daut et al., 2011).

In the absence of available data, several alternatives have been proposed for the purpose of obtaining daily estimates of GSI. There are many empirical methods that can be used to estimate solar irradiance, and these require the development of a set of empirical equations oriented towards estimating GSI from variables which are normally available in most meteorological stations (Almorox et al., 2011).

The models based on air temperature (Hargreaves \& Samani, 1982; Bristow \& Campbell, 1984; Richardson, 1985; Hunt, 1998; Chen et al., 2004) estimate the values of GSI as a function of extraterrestrial solar irradiance, which is based on either the concept of atmospheric transmittance (i.e, a linear function related to the duration of solar brightness) or the daily temperature range (Silva et al., 2012).

However, the importance of the calibration of these models for each site is emphasized, considering that the empirical relations vary spatially. Some authors (Mavromatis \& Jagtap, 2005; Liu et al., 2009; Almorox et al., 2011; Daut et al., 2011; Silva et al., 2012; Zirebwa et al., 2015) have evaluated these models in different locations (i.e., Chile, USA, China, Spain, Malaysia, Brazil and Zimbabwe, respectively) and their calibration coefficients varied considerably.

In this context, the objective of this study is to calibrate the parameters and to evaluate the performance of four empirical models of daily GSI estimation from daily air temperature data in eight localities of the state of Paraná, in southern Brazil.

\section{Material ANd Methods}

This research was developed in the Laboratory of Applied Computational Statistics - LECA of the Universidade Estadual de Ponta Grossa. Eight localities of the state of Paraná (Figure 1) were selected, and their climatological data from conventional meteorological stations (Table 1) were collected. The data are available in the Meteorological Database for Teaching and Research (BDMEP) of the Instituto Nacional de Meteorologia (INMET).

The state of Paraná belongs to the southern region of Brazil and is located between the parallels $22^{\circ} 30^{\prime} 58^{\prime \prime}$ and $26^{\circ} 43^{\prime} 00^{\prime \prime} \mathrm{S}$ latitude and between the meridians $48^{\circ} 5^{\prime} 37^{\prime \prime}$ and $54^{\circ} 37^{\prime} 8^{\prime \prime} \mathrm{W}$ longitude. According to Köppen's climate classification, the state has two types of climates: Cfa - Subtropical climate and Cfb - Temperate climate (IAPAR, 2018).

The daily historical series of insolation and temperatures of the examined localities comprised a period of 31 years (1987 to 2017). The data consistency procedure for the correction of

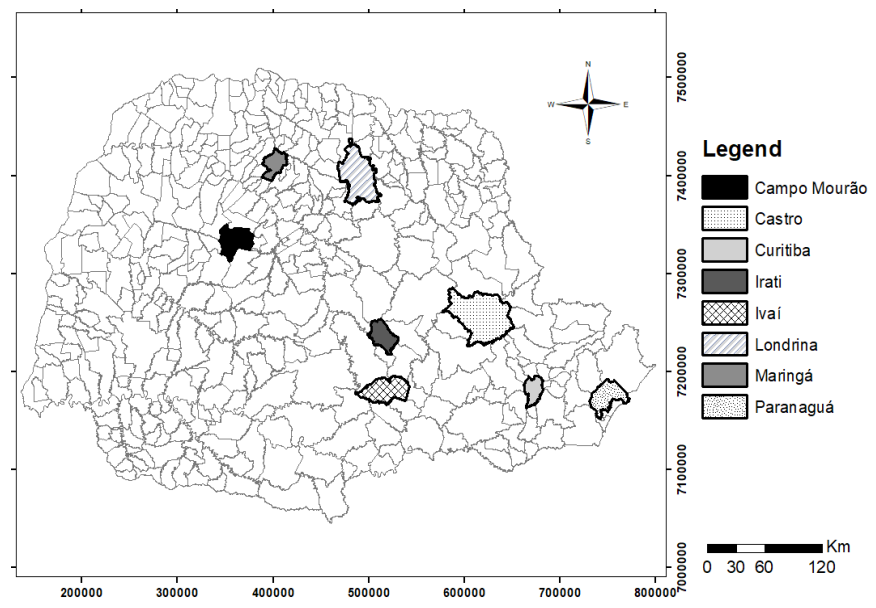

Figure 1. Selected locations in the state of Paraná, Brazil

Table 1. Geographical coordinates of selected locations

\begin{tabular}{llrrr}
\hline ID & Locality & Latitude (S) & Longitude (W) & Altitude (m) \\
\hline L1 & Campo Mourão & $24^{\circ} 5^{\prime}$ & $52^{\circ} 36^{\prime}$ & 616 \\
L2 & Curitiba & $24^{\circ} 78^{\prime}$ & $50^{\circ} 0^{\prime}$ & 1009 \\
L3 & Castro & $25^{\circ} 43^{\prime}$ & $49^{\circ} 26^{\prime}$ & 924 \\
L4 & Irati & $25^{\circ} 46^{\prime}$ & $50^{\circ} 63^{\prime}$ & 837 \\
L5 & Ivaí & $25^{\circ} 0^{\prime}$ & $50^{\circ} 85^{\prime}$ & 808 \\
L6 & Londrina & $23^{\circ} 31^{\prime}$ & $51^{\circ} 13^{\prime}$ & 566 \\
L7 & Maringá & $23^{\circ} 40^{\prime}$ & $51^{\circ} 91^{\prime}$ & 542 \\
L8 & Paranaguá & $25^{\circ} 53^{\prime}$ & $48^{\circ} 51^{\prime}$ & 5 \\
\hline
\end{tabular}

possible faults, as well as the calculation of the GSI from the sunshine data in the unit langley per day $\left(\mathrm{ly} \mathrm{d}^{-1}\right)$, were carried out through the software PGECLIMA_R (Virgens Filho et al., 2013).

Four models of GSI estimation (Table 2) were used with the air temperature data.

To compare the performance of the models, the KruskalWallis non-parametric test was used with the Dunn test for averages, at $\mathrm{p} \leq 0.05$. The analysis of the bias of the data estimated by the models in relation to the historical data was evaluated through the performance indices of Table 3.

According to Camargo \& Sentelhas (1997), Pearson's correlation coefficient indicates the degree of the data dispersion obtained in relation to the mean. The mean bias error (MBE) indicates the average "bias" of the model, i.e., medium or lower precision. The root mean square errors (RMSE) can vary from 0 to $\infty$, with the smaller value being the more accurate irradiance estimate. The Wilmott concordance index (d) defines the accuracy of the estimated values in relation to those that are observed, varying from 0 to 1 , with the value closer to one being the better estimate.

Table 2. Summary of models for daily irradiance estimation from the air temperature data used in the localities of Paraná state, Brazil

\begin{tabular}{|c|c|c|c|}
\hline ID & Model & Equation & Reference \\
\hline $\mathrm{Hg}$ & Hargreaves & $\mathrm{R}_{\mathrm{G}}=\mathrm{R}_{\mathrm{A}} \times(\mathrm{a}+\mathrm{b} \sqrt{\Delta \mathrm{T}})$ & $\begin{array}{c}\text { Hargreaves \& Samani } \\
\text { (1982) }\end{array}$ \\
\hline $\mathrm{R}$ & Richardson & $\mathrm{R}_{\mathrm{G}}=\mathrm{R}_{\mathrm{A}} \times\left(\mathrm{a}+\Delta \mathrm{T}^{\mathrm{b}}\right)$ & Richardson (1985) \\
\hline $\mathrm{Hu}$ & Hunt & $\mathrm{R}_{\mathrm{G}}=\left(\mathrm{b} \times \sqrt{\Delta \mathrm{T}} \times \mathrm{R}_{\mathrm{A}}\right)+\mathrm{a}$ & Hunt et al. (1998) \\
\hline $\mathrm{Ch}$ & Chen & $\mathrm{R}_{\mathrm{G}}=\mathrm{R}_{\mathrm{A}} \times(\mathrm{b} \ln \Delta \mathrm{T}+\mathrm{a})$ & Chen et al. (2004) \\
\hline
\end{tabular}

ID - Equation identifier; $R_{G}$ - Surface incident solar irradiance $\left(M J m^{-2} \mathrm{~d}^{-1}\right) ; R_{A}$ - Solar irradiance at the top of the atmosphere $\left(\mathrm{MJ} \mathrm{m}^{-2} \mathrm{day}^{-1}\right) ; \Delta \mathrm{T}$ - Daily thermal amplitude (difference between the maximum and minimum temperatures) $\left({ }^{\circ} \mathrm{C}\right) ; \mathrm{a}$ and $\mathrm{b}$ - Coefficients of the empirical models (dimensionless) 
Table 3. Performance indices used to analyze the bias

\begin{tabular}{|c|c|c|}
\hline Initials & Index & Equation \\
\hline$r$ & $\begin{array}{l}\text { Pearson } \\
\text { correlation } \\
\text { coefficient }\end{array}$ & $\mathrm{r}=\frac{\sum_{\mathrm{i}=1}^{\mathrm{n}}(\mathrm{x} \times \mathrm{y})-\left(\sum \mathrm{x}\right) \times\left(\sum \mathrm{y}\right)}{\sqrt{\mathrm{n} \sum \mathrm{x}^{2}-\left(\sum \mathrm{x}\right)^{2}} \times \sqrt{\mathrm{n} \sum \mathrm{y}^{2}-\left(\sum \mathrm{y}\right)^{2}}}$ \\
\hline MBE & $\begin{array}{l}\text { Mean bias } \\
\text { error }\end{array}$ & $\mathrm{MBE}=\frac{1}{\mathrm{n}} \sum_{\mathrm{i}=1}^{\mathrm{n}}(\mathrm{Pi}-\mathrm{Oi})$ \\
\hline RMSE & $\begin{array}{l}\text { Square root } \\
\text { mean square }\end{array}$ & RMSE $=\sqrt{\frac{1}{n}} \sum_{i=1}^{n}(P i-O i)^{2}$ \\
\hline$d$ & $\begin{array}{l}\text { Wilmott's } \\
\text { concordance } \\
\text { index }\end{array}$ & $\mathrm{d}=1-\left[\frac{\sum_{\mathrm{i}=1}^{\mathrm{n}}(\mathrm{Pi}-\mathrm{Oi})^{2}}{\sum_{\mathrm{i}=1}^{\mathrm{n}}(|\mathrm{Pi}-\overline{\mathrm{O}}|+|\mathrm{O} i-\overline{\mathrm{O}}|)^{2}}\right]$ \\
\hline C & $\begin{array}{l}\text { Performance } \\
\text { index "c" }\end{array}$ & $\mathrm{c}=\mathrm{r} \times \mathrm{d}$ \\
\hline NSE & $\begin{array}{l}\text { Nash- } \\
\text { Sutcliffe } \\
\text { efficiency } \\
\text { coefficient }\end{array}$ & $\mathrm{NSE}=1-\left[\frac{\sum_{\mathrm{i}=1}^{\mathrm{n}}(\mathrm{Oi}-\mathrm{Pi})^{2}}{\sum_{\mathrm{i}=1}^{\mathrm{n}}(\mathrm{Oi}-\overline{\mathrm{O}})^{2}}\right]$ \\
\hline
\end{tabular}

$\mathrm{Pi}$ - Estimated irradiance, Oi - Observed irradiance, $\mathrm{O}$ - Average of observed irradiance, $\mathrm{n}$ - Number of data

The values of the index "c" can vary between $-\infty$ and 1 , with the value above 0.85 being considered the optimal value (Camargo \& Sentelhas, 1997). The Nash-Sutcliffe efficiency coefficient is a normalized statistic that expresses the relative magnitude of the residual variance ("noise") in comparison with the variance of the measured data. The NSE values vary between $-\infty$ and 1 , where NSE $=1$ is the ideal value. In order to study the symmetry of the distributions and to detect the outliers, which consist of points sampled in the space whose values differ from the others, boxplot and line graphs were utilized in evaluating the annual trends of GSI values.

\section{Results AND Discussion}

Table 4 shows the parameter estimates of the tested models in each locality.

The distribution of the observed historical monthly averages (Obs) and of the models tested in the analyzed period of GSI for all evaluated locations are summarized in boxplot graphs (Figure 2).

For L1, the data of the Hg model presented high variability, having a mean and median with discrepant differences in relation to the observed values. The other models had mean and median values close to each other and similar to the observed values. Similarly, the performance of the models in L2, L3, and L4 are similar to that presented in L1, with high variability in $\mathrm{Hg}$ and similarity between $\mathrm{Ch}, \mathrm{Hu}$, and $\mathrm{Obs}$, except in L4, where the $\mathrm{R}$ model also presented similarity when compared to Obs.

Notwithstanding that for L1 to L4 and L7, the mean values of $\mathrm{Hg}$ are above the averages of the other models, this situation is reversed in L5, L6, and L8, i.e., the mean values presented are below the other models. For L5 and L7, the $\mathrm{Hg}$ values presented a very high variability. For L6 and L8, the $\mathrm{Hg}$ values were found to be well below those of the other models. For the locations L5 to L8, the models that approached the Obs were $\mathrm{Ch}$ and $\mathrm{Hu}$.

In the comparison of the means of GSI between the models and values observed, in Table 5, the Kruskal-Wallis test was used with the Dunn method. It was observed that for L1, the values of the $\mathrm{Ch}, \mathrm{Hu}, \mathrm{R}$, and Obs models did not differ statistically from each other, rather, they had a significant difference in relation to the $\mathrm{Hg}$ model. This behavior was verified throughout all the months, except for the month of June, in which all the models did not present any statistical significance among themselves. The same behavior was observed for L2, except for the month of October, in which the $\mathrm{R}$ model was shown to differ statistically from the others, less than $\mathrm{Hg}$.

For $\mathrm{L} 3$, the $\mathrm{Ch}, \mathrm{Hu}, \mathrm{Obs}$, and $\mathrm{R}$ models did not present statistical differences, except for the months of June and August, wherein the behavior observed for the $\mathrm{Ch}$ and $\mathrm{Hu}$ models did not present any statistical difference in relation to the observed values (Obs). However, all three statistically differed from $\mathrm{R}$ and $\mathrm{Hg}$, which, in turn, also presented statistical significance among themselves.

For L4, in the months of April and June, there was no statistical significance among the models. In the month of August, the $\mathrm{Ch}$ and $\mathrm{Hu}$ models were unable to present any statistical difference in relation to the observed values (Obs). However, the three statistically differed from $\mathrm{R}$ and $\mathrm{Hg}$, which, in turn, also presented statistical significance among themselves. In the month of December, it was shown that the $\mathrm{Hg}$ model differed statistically from the others, less than the $\mathrm{R}$ model, which is not different from other results. In the other months, the models $\mathrm{Ch}, \mathrm{Hu}, \mathrm{R}$, and Obs did not differ statistically among themselves; however, they had a significant difference in relation to the $\mathrm{Hg}$ model.

In L5, in the months of February, March, June, and July, the $\mathrm{Ch}, \mathrm{Hu}, \mathrm{R} \leq$ and Obs models did not differ statistically from one another, but they differed from the $\mathrm{Hg}$ model. In the months of January, May, October, November, and December, the $\mathrm{R}$ and $\mathrm{Hg}$ models differed from each other. In April, only

Table 4. Parameter estimates of the tested models in each locality

\begin{tabular}{|c|c|c|c|c|c|c|c|c|}
\hline \multirow{3}{*}{ Localities } & \multicolumn{8}{|c|}{ Models } \\
\hline & \multicolumn{2}{|c|}{$\mathrm{Ch}$} & \multicolumn{2}{|c|}{$\mathrm{Hg}$} & \multicolumn{2}{|c|}{$\mathrm{Hu}$} & \multicolumn{2}{|c|}{$\overline{\mathbf{R}}$} \\
\hline & a & $\bar{b}$ & a & b & $a$ & $\bar{b}$ & $\bar{a}$ & $\bar{b}$ \\
\hline L1 & -0.159 & 0.288 & -0.063 & 0.176 & -2.50 & 0.177 & 0.119 & 0.626 \\
\hline L2 & -0.026 & 0.194 & -0.006 & 0.132 & 0.699 & 0.129 & 0.214 & 0.513 \\
\hline L3 & -0.117 & 0.261 & -0.089 & 0.178 & -3.806 & 0.178 & 0.121 & 0.601 \\
\hline L4 & -0.059 & 0.227 & -0.049 & 0.159 & -2.136 & 0.158 & 0.140 & 0.533 \\
\hline L5 & 0.115 & 0.158 & 0.103 & 0.116 & 4.184 & 0.115 & 0.250 & 0.362 \\
\hline L6 & 0.309 & 0.098 & 0.363 & 0.054 & 11.942 & 0.053 & 0.356 & 0.214 \\
\hline L7 & -0.061 & 0.263 & 0.003 & 0.169 & -0.235 & 0.169 & 0.204 & 0.543 \\
\hline L8 & 0.340 & 0.037 & 0.359 & 0.019 & 12.429 & 0.021 & 0.305 & 0.177 \\
\hline
\end{tabular}

See Tables 1 and 2 for description of the localities and of the models, respectively. See Table 2 for description of the model 

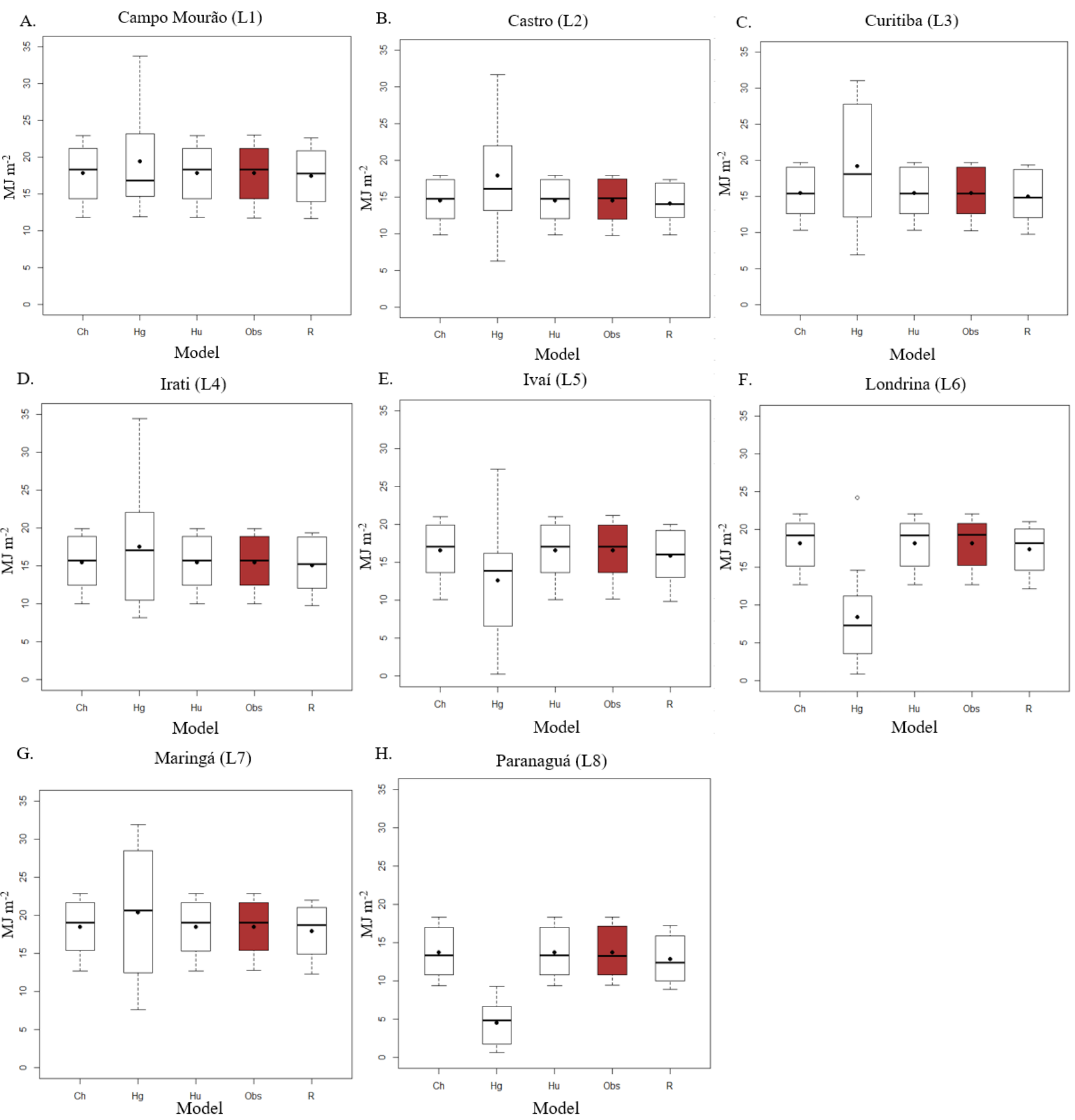

See Table 2 for description of the models

Figure 2. The estimated and measured values of global solar irradiance (GSI) in L1 (A), L2 (B), L3 (C), L4 (D), L5 (E), L6 (F), L7 (G), and L8 (H) for the period between 1987 and 2017

the $\mathrm{Hg}$ and $\mathrm{R}$ models differed from each other. In August, the $\mathrm{Hg}$ model differed statistically from the others, less than the $\mathrm{R}$ model, which differs from none of the others. Moreover, in the month of September, the observed values did not differ from those of the $\mathrm{Ch}$ and $\mathrm{Hu}$ models, which, in turn, did not differ from those of the $\mathrm{R}$ model, but the $\mathrm{Hg}$ model differed statistically from all of them.

For L6, in the months of January and May, the Hg model differed statistically from the others, whereas for the other months, the observed values do not differ from $\mathrm{Ch}$ and $\mathrm{Hu}$. However, the $\mathrm{Hg}$ and $\mathrm{R}$ models differed from each other and from the others. In L7, only the Hg model differed statistically from the others in the months of January, February, March,
August, September, October, and December. In April, May, July, and November, the observed values did not differ from $\mathrm{Ch}$ and $\mathrm{Hu}$, however, the $\mathrm{Hg}$ and $\mathrm{R}$ models differed from each other. In June, the statistical significance was found only between the $\mathrm{Hg}$ and $\mathrm{R}$ models. For L8, it was only in September and only in the $\mathrm{Hg}$ model that the statistical significance was found. For the other months, it was verified that the observed values did not differ from $\mathrm{Ch}$ and $\mathrm{Hu}$, however, the $\mathrm{Hg}$ and $\mathrm{R}$ models differed from each other.

Table 6 presents the results of the performance indices of the models for all the locations, i.e., from L1 to L8. The highlighted values indicate the best result of each index, for each analyzed model. It was observed that for L1, L6, L7, and 
Table 5. Dunn test result for comparison among models

\begin{tabular}{|c|c|c|c|c|c|c|c|c|c|c|c|c|}
\hline & Jan & Feb & Mar & Apr & May & Jun & Jul & Aug & Sep & Oct & Nov & Dec \\
\hline \multicolumn{13}{|c|}{ L1 - Campo Mourão } \\
\hline $\mathrm{Ch}$ & $b$ & $b$ & $\mathrm{a}$ & a & $b$ & $\mathrm{a}$ & $b$ & $\mathrm{a}$ & $b$ & $b$ & $\mathrm{a}$ & $\mathrm{b}$ \\
\hline $\mathrm{Hg}$ & a & $\mathrm{a}$ & b & b & a & $\mathrm{a}$ & $\mathrm{a}$ & b & a & a & c & $\mathrm{a}$ \\
\hline $\mathrm{Hu}$ & b & b & a & a & b & $a$ & $\mathrm{~b}$ & a & b & b & a & b \\
\hline Obs & b & $b$ & $\mathrm{a}$ & $\mathrm{a}$ & $\mathrm{b}$ & $\mathrm{a}$ & b & $\mathrm{a}$ & b & $b$ & $\mathrm{a}$ & b \\
\hline $\mathrm{R}$ & b & b & $\mathrm{a}$ & $\mathrm{a}$ & b & $\mathrm{a}$ & $\mathrm{b}$ & $\mathrm{a}$ & b & $\mathrm{b}$ & b & $\mathrm{b}$ \\
\hline \multicolumn{13}{|c|}{ L2 - Curitiba } \\
\hline $\mathrm{Ch}$ & $b$ & a & $b$ & a & $b$ & b & a & $b$ & a & a & $b$ & b \\
\hline $\mathrm{Hg}$ & $a$ & b & $a$ & b & a & $a$ & b & $a$ & b & $a b$ & a & $a$ \\
\hline $\mathrm{Hu}$ & b & a & b & a & b & b & $a$ & b & a & $a$ & b & b \\
\hline Obs & b & a & b & a & b & b & $\mathrm{a}$ & $b$ & $\mathrm{a}$ & $\mathrm{a}$ & $b$ & b \\
\hline $\mathrm{R}$ & b & a & b & a & b & b & $\mathrm{a}$ & $\mathrm{b}$ & $\mathrm{a}$ & $b$ & $b$ & $\mathrm{~b}$ \\
\hline \multicolumn{13}{|c|}{ L3 - Castro } \\
\hline $\mathrm{Ch}$ & $b$ & $b$ & $b$ & $b$ & $a$ & $a$ & $b$ & $a$ & $b$ & a & $b$ & $b$ \\
\hline $\mathrm{Hg}$ & a & a & a & a & b & C & a & C & a & b & a & $a$ \\
\hline $\mathrm{Hu}$ & b & $b$ & $b$ & $b$ & $\mathrm{a}$ & $\mathrm{a}$ & b & $\mathrm{a}$ & $b$ & a & b & b \\
\hline Obs & b & b & b & $\mathrm{b}$ & $\mathrm{a}$ & $\mathrm{a}$ & b & $\mathrm{a}$ & b & a & b & $\mathrm{b}$ \\
\hline $\mathrm{R}$ & b & b & b & b & a & b & $b$ & b & b & $a$ & b & b \\
\hline \multicolumn{13}{|c|}{ L4 - Irati } \\
\hline $\mathrm{Ch}$ & $b$ & $b$ & $b$ & a & a & $a$ & $b$ & $a$ & $a$ & $b$ & $b$ & a \\
\hline $\mathrm{Hg}$ & $a$ & a & a & a & b & a & a & C & $b$ & a & a & b \\
\hline $\mathrm{Hu}$ & b & b & b & a & a & $\mathrm{a}$ & b & $a$ & $\mathrm{a}$ & b & b & a \\
\hline Obs & b & b & b & $a$ & a & $\mathrm{a}$ & b & a & $a$ & b & $\mathrm{b}$ & $a$ \\
\hline $\mathrm{R}$ & b & b & b & a & a & a & b & $\mathrm{b}$ & $a$ & b & b & $a b$ \\
\hline \multicolumn{13}{|c|}{ L5 - Ivaí } \\
\hline $\mathrm{Ch}$ & $a$ & b & b & $a b$ & a & b & b & a & $a b$ & a & a & $a$ \\
\hline $\mathrm{Hg}$ & C & $\mathrm{a}$ & $\mathrm{a}$ & $\mathrm{a}$ & C & a & $\mathrm{a}$ & $b$ & C & C & C & C \\
\hline $\mathrm{Hu}$ & $a$ & b & b & $a b$ & a & b & b & a & $a b$ & $a$ & a & $\mathrm{a}$ \\
\hline Obs & $a$ & b & b & $a b$ & a & b & b & a & a & a & a & $a$ \\
\hline $\mathrm{R}$ & b & b & b & $\mathrm{b}$ & b & b & $\mathrm{b}$ & $a b$ & b & b & b & b \\
\hline \multicolumn{13}{|c|}{ L6 - Londrina } \\
\hline $\mathrm{Ch}$ & $b$ & $\mathrm{a}$ & $a$ & a & b & a & a & $a$ & $\mathrm{a}$ & a & $a$ & $\mathrm{a}$ \\
\hline $\mathrm{Hg}$ & $\mathrm{a}$ & C & C & C & a & C & C & C & C & C & C & C \\
\hline $\mathrm{Hu}$ & $b$ & $a$ & $a$ & a & $b$ & $\mathrm{a}$ & $a$ & $a$ & $\mathrm{a}$ & $a$ & a & $a$ \\
\hline Obs & b & $a$ & $a$ & a & b & a & $a$ & a & a & a & a & a \\
\hline $\mathrm{R}$ & b & b & b & $b$ & b & b & b & $b$ & b & $b$ & b & b \\
\hline \multicolumn{13}{|c|}{ L7 - Maringá } \\
\hline $\mathrm{Ch}$ & $b$ & $\mathrm{a}$ & $b$ & $\mathrm{a}$ & $\mathrm{a}$ & $a b$ & $a$ & $b$ & $b$ & $b$ & $a$ & a \\
\hline $\mathrm{Hg}$ & $\mathrm{a}$ & $b$ & $\mathrm{a}$ & C & C & $\mathrm{a}$ & C & $a$ & $\mathrm{a}$ & $\mathrm{a}$ & C & b \\
\hline $\mathrm{Hu}$ & b & a & b & a & a & $a b$ & $a$ & b & b & b & a & a \\
\hline Obs & $\mathrm{b}$ & $a$ & b & $\mathrm{a}$ & a & $a b$ & $a$ & $\mathrm{~b}$ & b & $\mathrm{b}$ & a & $\mathrm{a}$ \\
\hline $\mathrm{R}$ & b & $a$ & $b$ & b & b & b & b & b & b & b & b & $a$ \\
\hline \multicolumn{13}{|c|}{ L8 - Paranaguá } \\
\hline $\mathrm{Ch}$ & $a$ & $\mathrm{a}$ & $\mathrm{a}$ & a & a & $\mathrm{a}$ & $\mathrm{a}$ & $\mathrm{a}$ & $\mathrm{a}$ & $\mathrm{a}$ & a & $a$ \\
\hline $\mathrm{Hg}$ & c & C & c & C & C & c & c & c & $b$ & C & C & C \\
\hline $\mathrm{Hu}$ & $a$ & a & a & a & a & a & $\mathrm{a}$ & a & a & a & a & $a$ \\
\hline Obs & $a$ & $a$ & a & a & a & a & $\mathrm{a}$ & $a$ & $\mathrm{a}$ & $\mathrm{a}$ & $\mathrm{a}$ & $\mathrm{a}$ \\
\hline $\mathrm{R}$ & b & b & b & b & b & b & b & b & $\mathrm{a}$ & b & b & b \\
\hline
\end{tabular}

See Tables 1 and 2 for the descriptions of the localities and of the models, respectively.

Same letters in the column for all months and locations do not differ statistically from each other at $\mathrm{p} \leq 0.05$ according to the Dunn test

L8, the model of Ch presented a higher number of highlighted values, followed by the Hu model, with similar performance. For L2, L3, L4, and L5, the Hu model was the most impressive model, followed by the Ch model. For L3 and L4, the Ch model also presented good results for the indices, with a performance similar to the Hu model. It should be noted that for L2, L5, and L8, the applied statistical indices did not present good results for the models in this locality.

Figure 3 shows the annual trends of observed and estimated $\mathrm{R}_{\mathrm{G}}$ values through the studied models per locality. It was observed that the $\mathrm{Ch}$ and $\mathrm{Hu}$ models showed a behavior similar to that of the observed values, for all localities, with values very close to each other. For these models, the annual $R_{G}$ values varied between 8 and $23 \mathrm{MJ} \mathrm{m}^{-2} \mathrm{~d}^{-1}$, considering all the locations.
The model of $\mathrm{R}$ showed a seasonal behavior similar to that of the observed values. However, the data estimated by this model were approximately $3.6 \%$ lower than those observed for all the localities. On the other hand, the $\mathrm{Hg}$ model presented the worst annual trend for all the localities. The values oscillated every month, sometimes the model overestimated the data, and sometimes it underestimated them. The $\mathrm{Hg}$ model reached values of $R_{G}$ between 0.26 and $33.7 \mathrm{MJ} \mathrm{m}^{-2} \mathrm{~d}^{-1}$, very extreme values when compared with those observed and obtained using the $\mathrm{Ch}$ and $\mathrm{Hu}$ models.

As for the calibrated coefficients of the models, considering all the localities, the values for coefficient a of the Ch model varied between -0.548 and 0.973 , while those for coefficient $\mathrm{b}$ varied between -0.232 and 0.467 . For the $\mathrm{Hg}$ model, the 
Table 6. Performance indices of the models for each locality

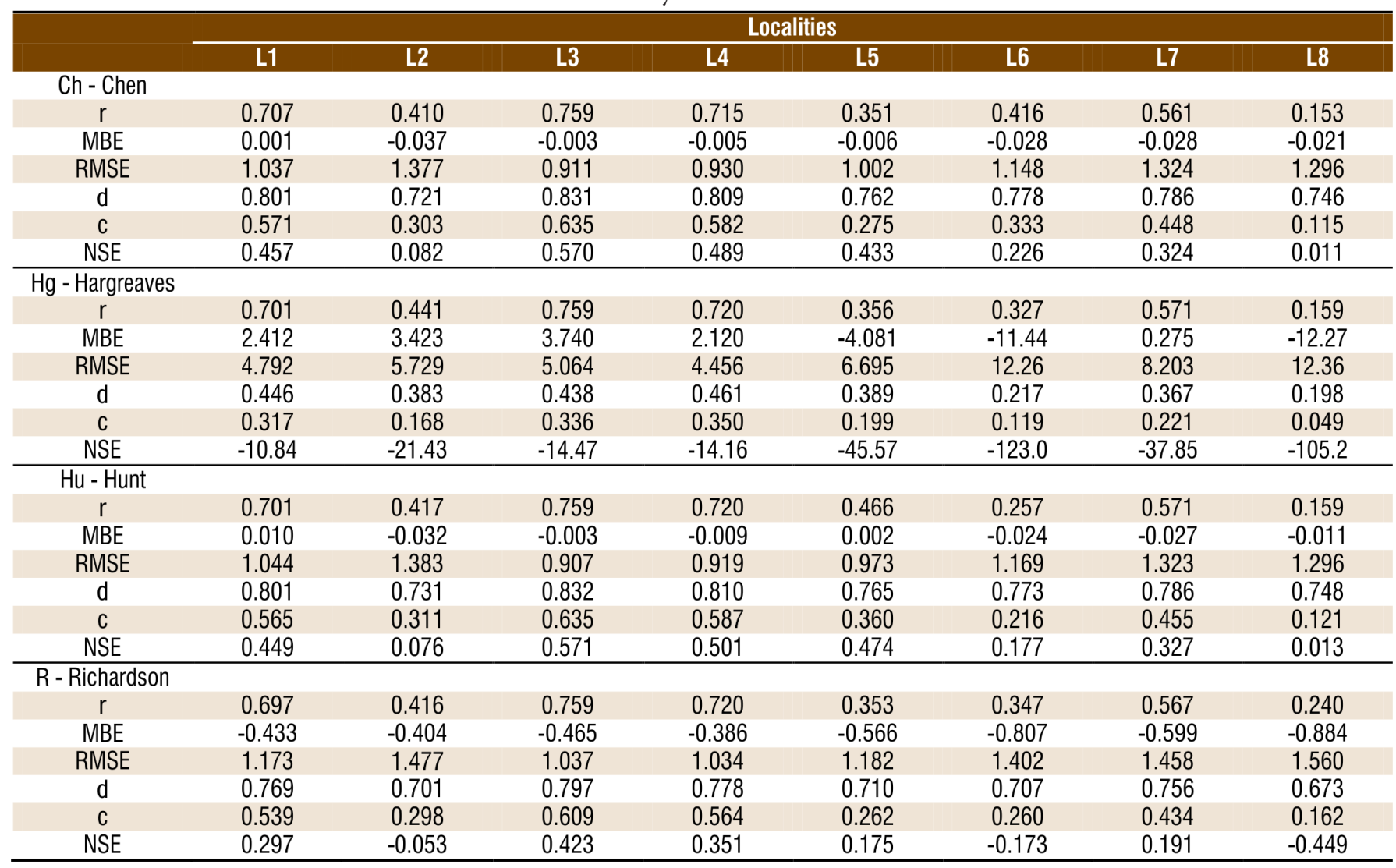

See Tables 1, 2 and 3 for description of localities, models, and performance indices, respectively

values for coefficient a ranged from -0.453 to 0.995 , while those for coefficient $b$ varied from -0.172 to 0.311 . The values for coefficient a of the $\mathrm{Hu}$ model varied between -17.505 and 27.742 and those for coefficient $b$ varied between -0.178 and 0.313 . For the $\mathrm{R}$ model, the coefficient a values ranged from 0.046 to 0.906 , while the coefficient $b$ values ranged from -0.304 to 0.995 .

For the Ch model, Monteiro \& Martins (2019) found annual values for coefficient a of 0.199 and those for coefficient $b$ of -0.172 for Viçosa, MG, Brazil. For the same state, Silva et al. (2012) found values of coefficient a equal to 0.315 and those of coefficient b equal to -0.458. Similarly, Chen et al. (2004) obtained coefficient a values between 0.16 and 0.42 and coefficient $b$ values between -0.45 and 0.12 for China.

The differences in values are due to the differences in the characteristics of the sites studied. They are also due to the adjustment, which, on the one hand, was conducted annually in the cited studies, while in this study, on the other hand, it was conducted on a monthly basis. Buriol et al. (2012) stressed the importance of adjusting the coefficients on a monthly basis.

By means of the boxplot graphs (Fig. 2), it became possible to verify that, for all the localities, the $\mathrm{Ch}$ and $\mathrm{Hu}$ models were those that approached the observed values, thereby making it possible to use these models in these localities. The $\mathrm{R}$ model only showed similarity to Obs in the L4 locality. It was likewise observed that the $\mathrm{Hg}$ model showed great variability, making the use of such model impractical, since it can lead to estimates of very extreme values.

The $\mathrm{Ch}$ and $\mathrm{Hu}$ models did not differ statistically from the values observed in any month, according to the Dunn test (Table
5). In general, it was observed that the $\mathrm{Hg}$ model presented statistical significance in relation to the other models and values that have been observed for many months. It was also verified that the $\mathrm{R}$ model exhibited oscillation regarding the significance.

As for the studied statistical indices (Table 6), the models that presented the highest efficiency were $\mathrm{Hu}$ and $\mathrm{Ch}$, with both of them having equivalent performance. The results of the indices showed a noticeable oscillation between very bad values and good values, according to each month and locality. Although the $\mathrm{Hg}$ model was unable to present a satisfactory performance for the studied localities of Paraná, Daut et al. (2011) found an excellent performance of this model for Malaysia, with an NSE value above 0.8. Chen et al. (2004) found an unsatisfactory NSE value of 0.44 for China, which confirms that the model performance is influenced by the locality factor, which, in turn, is related to its local climatology.

The annual trends of observed and estimated $\mathrm{R}_{\mathrm{G}}$ values (Fig. 3) showed that the $\mathrm{Ch}$ and Hu models showed a behavior similar to that of the observed values for all the locations, with values very close to each other. On the other hand, the $\mathrm{Hg}$ model presented the worst annual trend.

For the city of Viçosa (MG state), Monteiro \& Martins (2019) found that the Ch model was very similar to the other models and accurate for estimate solar irradiance. The $\mathrm{Ch}$ model was superior in estimating in the months of spring and fall, while the $\mathrm{Hu}$ model was superior for the months of summer and winter. For the localities in China, Chen et al. (2004) showed that the presented model (Ch) obtained an NSE value of 0.85 , which is considered good, and that this model was efficient for the region. 
A.

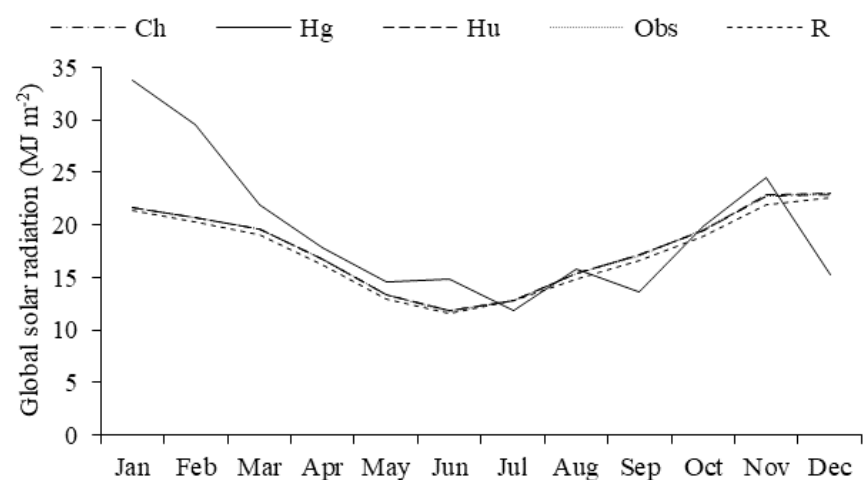

C.

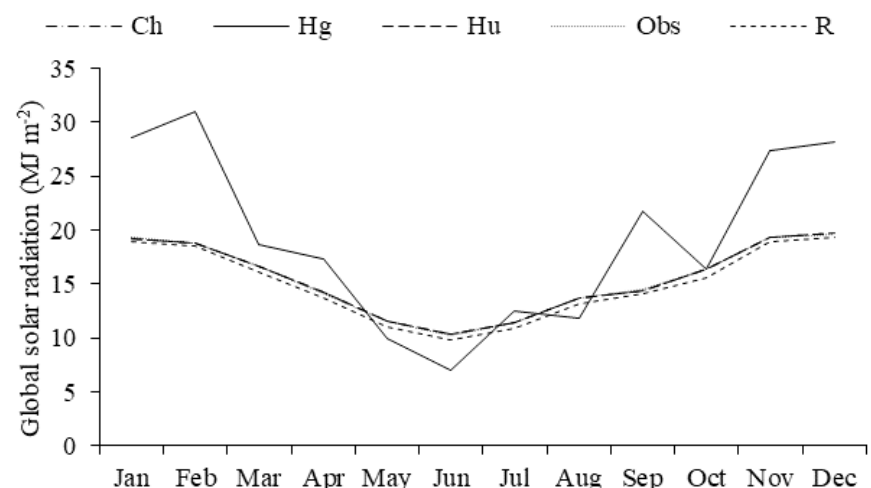

E.

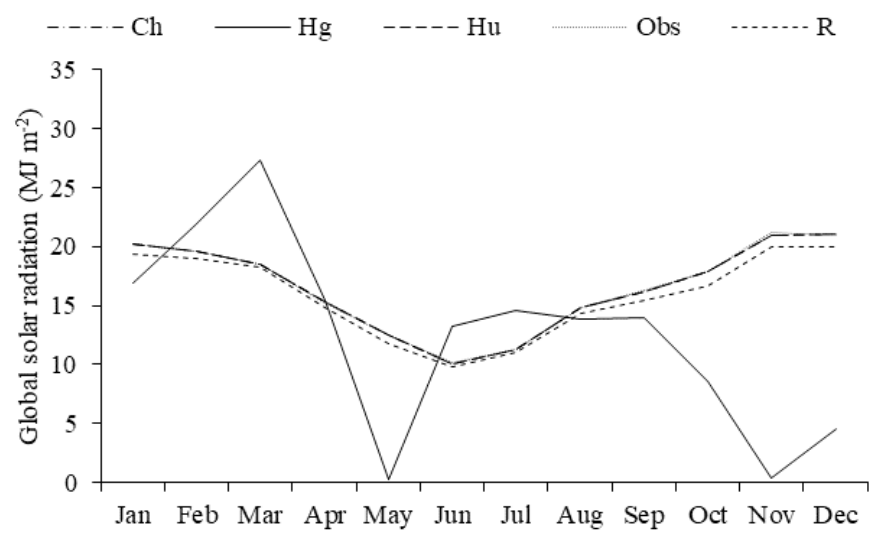

G.

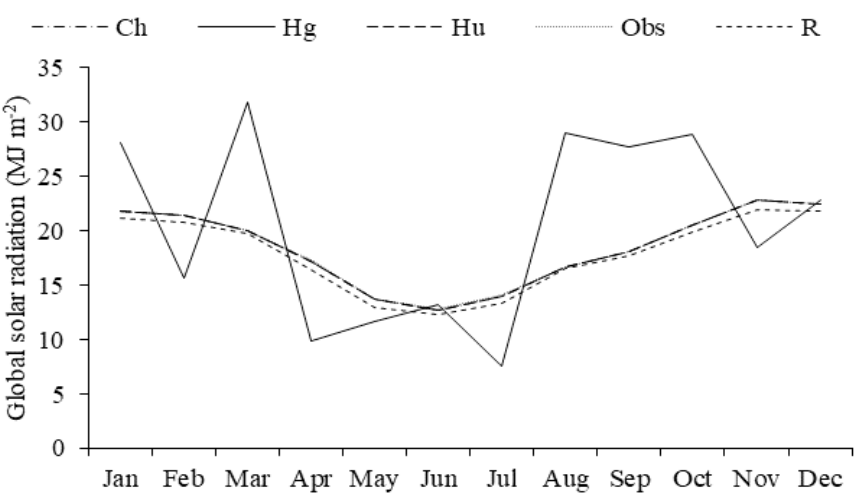

B.

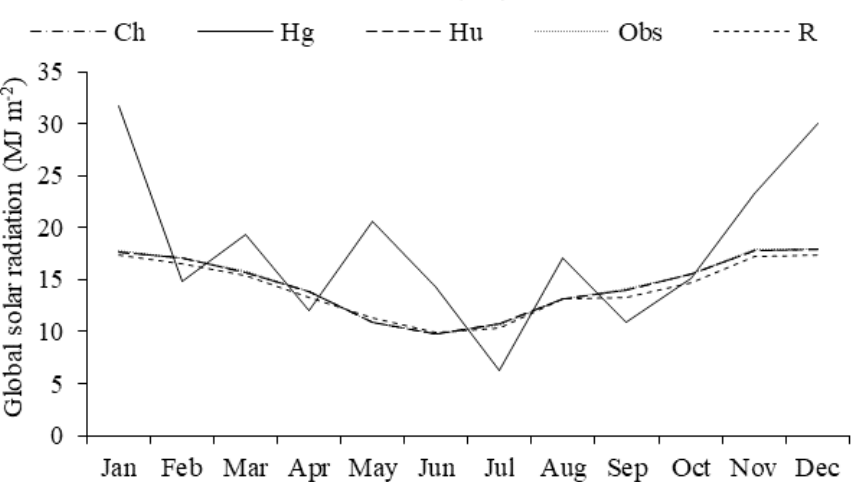

D.

Irati (L4)

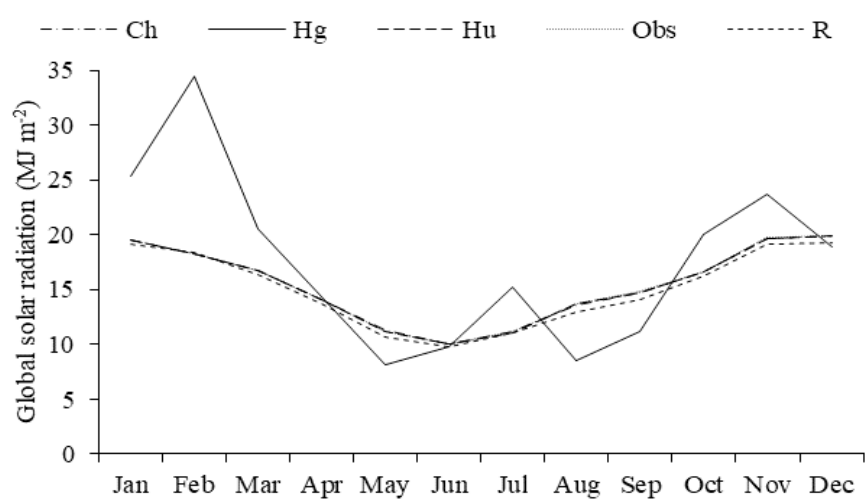

F. Londrina (L6)

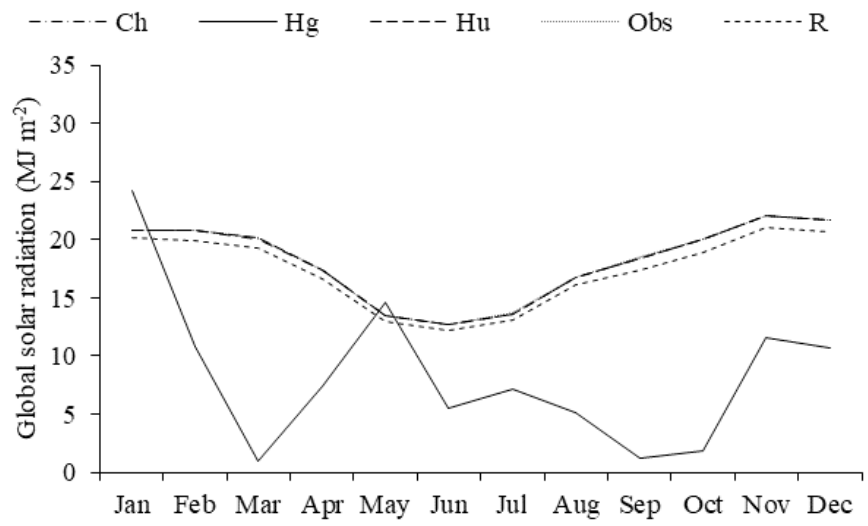

H. Paranaguá (L8)

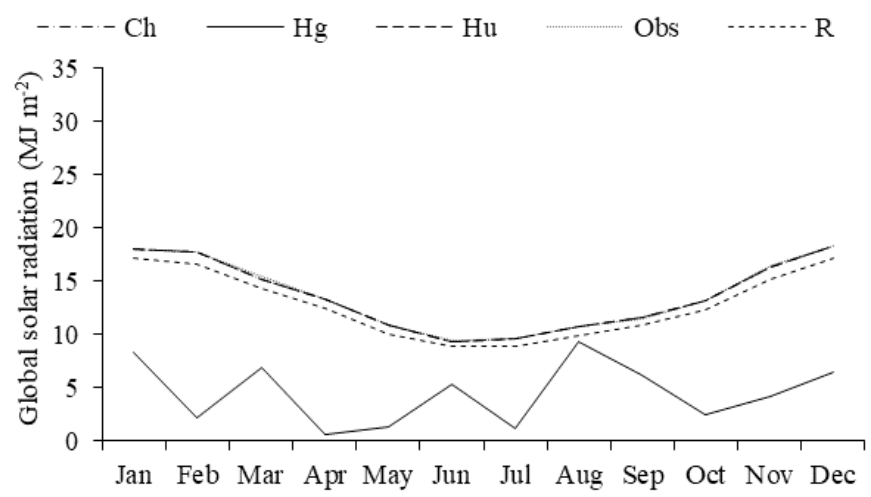

See Table 2 for the description of the models

Figure 3. Annual trends of observed and estimated $\mathrm{R}_{\mathrm{G}}$ values for L1 (A), L2 (B), L3 (C), L4 (D), L5 (E) L6 (F), L7 (G), and L8 (H) 


\section{Conclusion}

The models proposed by Chen and Hunt showed the best performances in the estimation of GSI for the evaluated localities of Paraná, Brazil, given that they presented an annual trend and average values similar to those of the observed historical data.

\section{ACKNowledgments}

The authors would like to thank CNPq for the financial support of the research.

\section{Literature Cited}

Almorox, J.; Hontoria, C.; Benito, M. Models for obtaining daily global solar irradiance with measured air temperature data in Madrid (Spain). Applied Energy, v.88, p.1703-1709, 2011. https:/doi. org/10.1016/j.apenergy.2010.11.003

Bristow, K. L; Campbell, G. S. On the relationship between incoming solar irradiance and daily maximum and minimum temperature. Agricultural and Forest Meteorology, v.31, p.159-166, 1984. https://doi.org/10.1016/0168-1923(84)90017-0

Buriol, G. A.; Estefanel, V.; Heldwein, A. B.; Prestes, S. D.; Horn, J. F. C. Estimativa da irradiância solar global a partir dos dados de insolação, para Santa Maria-RS. Ciência Rural, v.42, p.1563-1567, 2012. https://doi.org/10.1590/S0103-84782012005000059

Camargo, A. P.; Sentelhas, P. C. Avaliação do desempenho de diferentes métodos de estimativa da evapotranspiração potencial no estado de São Paulo. Revista Brasileira de Agrometeorologia, v.5, p.89-97, 1997.

Chen, R.; Ersi, K.; Yang, J.; Lu, S.; Zhao, W. Validation of five global irradiance models with measured daily data in China. Energy Conversion and Management, v.45, p.1759-1769, 2004. https:// doi.org/10.1016/j.enconman.2003.09.019

Daut, I.; Irwanto, M.; Irwan, Y. M.; Gomes, N.; Ahmad, N. S. Combination of Hargreaves method and linear regression as a new method to estimate solar irradiance in Perlis, Northern Malaysia. Solar Energy, v.85, p.2871-2880, 2011. https://doi.org/10.1016/j. solener.2011.08.026
Hargreaves, G. H.; Samani, Z. A. Estimating potencial evapotranspiration. Journal of Irrigation and Drainage Engineering, v.108, p.225-230, 1982.

Hunt, L. A. Estimation of solar irradiance for use in crop modeling. Agricultural and Forest Meteorology, v.91, p.293-300, 1998. https://doi.org/10.1016/S0168-1923(98)00055-0

IAPAR - Instituto Agronômico do Paraná. Cartas climáticas do Paraná. Available on: <http://www.iapar.br/modules/conteudo/ conteudo.php?conteudo=863>. Accessed on:Nov. 2018.

Liu, X.; Mei, X.; Li, Y.; Wang, Q.; Jensen, J.R.; Zhang, Y.; Porter, J. R. Evaluation of temperature-based global solar irradiance models in China. Agriculture and Forest Meteorology, v.149, p.1433-1446, 2009. https://doi.org/10.1016/j.agrformet.2009.03.012

Mavromatis, T.; Jagtap, S. S. Estimating solar irradiance for crop modeling using temperature data from urban and rural stations. Climate Research, v.29, p.233-243, 2005. https://doi.org/10.3354/cr029233

Monteiro, A. F. M.; Martins, F. B. Estimativa da irradiância solar global para Viçosa (MG) com dados de entrada de fácil medição. Revista Hipótese, v.5, p.385-398, 2019.

Podestá, G.P.; Núñez, L.; Villanueva, C. A.; Skansi, M. A. Estimating daily solar irradiance in the Argentine Pampas. Agricultural and Forest Meteorology, v.123, p.41-53, 2004. https://doi.org/10.1016/j. agrformet.2003.11.002

Richardson, C. W. Weather simulation for crop management models. Transactions of the American Society of Agricultural Engineers, v.28, p.1602-1606, 1985. https://doi.org/10.13031/2013.32484

Silva, C. R. da; Silva, V. J. da; Alves Júnior, J.; Carvalho, H. de P. Irradiância solar estimada com base na temperatura do ar para três regiões de Minas Gerais. Revista Brasileira de Engenharia Agrícola e Ambiental, v.16, p.281-288, 2012. https://doi.org/10.1590/S141543662012000300008

Virgens Filho, J. S. das; Oliveira, R. B. de; Leite, M. de L.; Tsukahara, R. Y. Desempenho dos modelos CLIGEN, LARS-WG e PGECLIMA_R na simulação de séries diárias de temperatura máxima do ar para localidades do estado do Paraná. Engenharia Agrícola, v.33, p.538547, 2013. https://doi.org/10.1590/S0100-69162013000300010

Zirebwa, F.S.; Kapenzi, A.; Makuvaro, V.; Sammie, B.; Madanzi, T. An evaluation of the performances and subsequent calibration of three solar irradiance estimation models for semi arid climates in Mildlands Zimbabwe. Journal of Science, Agriculture and Technology, v.special, p.44-55, 2015. 